Marina Đorđević ${ }^{1}$

Dušan Perović ${ }^{2}$

University of Niš,

Faculty of Economics
SCIENTIFIC REVIEW ARTICLE

doi:10.5937/ekonomika1603057D

Received: June 29, 2016

Accepted: Septembar 9, 2016

\title{
CRISIS IMPACT ON CHANGES IN IMPLEMENTING MONETARY POLICY OF CENTRAL BANKS
}

\begin{abstract}
The aim of the paper is to show how last global financial crisis changed the way of managing monetary policy and what were the consequences of a long time passive behaviour of central banks. Evolutionary characteristics of monetary and real shocks have changed the traditional way of understanding crisis and it brought huge changes in modern monetary policies implementation. The starting hypothesis in this paper is that common monetary measures are not sufficient for solving crisis. This hypothesis will be tested through the analysis of FED, ECB and BoJ monetary actions during the crisis with the use of comparative-analytic method.
\end{abstract}

Keywords: crisis, monetary strategy, central banks, cash flow, market

JEL classification: E51,E52, E58, G01

\section{УТИЦАЈ КРИЗЕ НА ПРОМЕНЕ У НАЧИНУ ВОЪЕЊА МОНЕТАРНЕ ПОЛИТИКЕ ЦЕНТРАЛНИХ БАНАКА}

\begin{abstract}
Апстракт
Циљ рада је да покаже како је последюа финансијска криза утицала на промене у вођењу монетарне политике, као и са каквим су се последицама суочиле иентралне банке након вишегодишье пасивне улоге у вођењу монетарне политике. Еволутивни карактер монетарних и реалних шокова у великој мери изменио је традиционални начин схватања криза и довео је до крупних промена у савременом вођењу монетарне политике. Полазна претпоставка у раду је да уобичајне мере нису довољне за решавање кризе, због чега ће ова претпоставка бити тестирана кроз анализу монетарних акција иентралних банака САД, ЕУ и Јапана употребом компаративноаналитичког метода.
\end{abstract}

Кључне речи: криза, монетарна стратегија, иентралне банке, новчани ток, тржиште

\footnotetext{
${ }^{1}$ marinadj@ptt.rs

${ }^{2}$ bokaperovic@yahoo.com
} 


\section{Introduction}

For recent crisis big responsibility had neoliberal concept. Neoliberalism has focus on the radical individualism, economic liberalisation, deregulation, "free market", the reduction of state role in economy and public sector privatisation (Peric, Maric, 2015). This doctrine influenced many central banks to permit bigger money supply in order to achieve higher economic growth rate. Inflation rates were higher, but they could be still well controlled by monetary authorities.

Expansionary monetary policy was not sustainable any more back in 2007 . When financial crisis emerged in USA and was quickly spread all over the world, that was a signal for monetary authorities that they have to change something quickly or they will have bigger problems in future. The collapse of major financial firms led to a series of a panics on global stock markets, wiping trillions of dollars off the value of stock (Beder, 2009). Lower share prices combined with less credit supply brought uncertainty for future investments, which caused lower economic activity and in the end higher unemployment rate and recession.

Authors have started from basic point where traditional mechanisms are not so effective for solving last crisis, if characteristics and intensity of crisis are involved. Paper is structured so beside introduction and conclusion has three parts. First part brings brief analysis of crisis at monetary sector and factors that caused problems. Second part gives closer look to actions that many central banks implemented in order to alleviate crisis effects and set monetary sector on right track. Third part brings analysis of major central banks behaviour, where will be made deeper analysis of actions that changed the typical way of monetary thinking.

\section{Monetary sector as a cause of the outbreak of the crisis}

Monetary policy has task to implement effective controll of money supply, because stability of monetary sector leads to overall economic stability (Hubbard, 2005). Before taking a decision about monetary policy, business cycles and basic economic situation inside and outside of national economy must be carefully observed. Optimal structure of monetary policy depends from: a) publics ability to predict policy makers actions, b) the policy makers goals, c) the predictability of linkages between policy tools and goals, d) the extent of shocks to economy and e) the perceived credibility of policy makers (Englander, 1991).

Global economic and financial crisis was a result of too much deregulation at some markets. Mortgage market was one of primary triggers for crisis, but large responsibility lies also on Federal Reserves (FED). With bigger availability of credits many people have started to buy flats and houses and that increased overall sale in real estate area. As prices of real estates were on constant increase, subprimary mortgage market was formed. Subprime market was responsible for outbreak of the crisis due to lack of regulation. With too many houses and apartments sold with the assistance of cheap credits, real estate bubble was created and later caused problems first in USA and later in the world (Veselinovic, 2012, p. 434-436).

From 2000 to 2006 FED lowered reference interest rate from 6,24 to 4,96\% with note that interest rate in 2003 was $1,13 \%$ which was at the lowest level ever. This 
encouraged borrowing from abroad in order to finance huge current account deficit. FED's decision to slightly increase interest rate from 2004 to 2006 caused increase of short and long-term adjustable rate mortgage rates making them expensive for house owners. As housing prices started to decline, borrowers could not finance their obligations and this led to bankruptcy of many banks and depository institutions that gave mortgage loans.

European Central Bank (ECB) is responsible for monetary policy of EU and it implements monetary strategy that can be viewed as a modified version of inflation planning where central bank tries to avoid precise assessment or volume for mediumterm inflation, while it uses explicit nominal anchor (M1 or M3 aggregates) for longterm inflation expectations (Borde \& Clerc, 2004, p.12). ECB aims at inflation rates of below, but close to $2 \%$ over the medium term.

At the end of 2007 average inflation rate reached 2,17\% and this called for monetary actions. Concerned for price stability ECB raised interest rates twice. As a result, the minimum bid rate in the main refinancing operations of Eurosystem was at level of $4,00 \%$ in June 2007. Having seen the situation in USA, many banks in Europe have started to rely on liquidity from Eurosystem and they have provided less money for interbanking market. During June and July 2008 inflation rate reached 4\% and that was a signal for ECB to raise interest rates in order to prevent deeper crisis. ECB interest rates were raised by 25 basis points in July. With higher interest rates, by the end of year inflation rate declined to $1,6 \%$, but additional problem was that during the $2008 \mathrm{EU}$ entered recession with negative growth rates in second $(-0,1 \%)$, third $(-0,3 \%)$ and fourth quarter $(-1,5 \%)$ (Fahr et al., 2011). High interest rates have caused less money supply on market which was necessary for investments. Low growth rate and recession had impact on increasing unemployment rate to $9,4 \%$ in EU and caused sovereign debt crisis in countries like Greece, Ireland and Portugal.

Bank of Japan (BoJ) has implemented expansionary monetary policy for a very long time. Low interest rates $(0,1-0,5 \%)$ were supportive for attracting more funds into domestic industry and foreign trade. Japan was also struggling with deflation, so low rates were needed for improving economic conditions. With the outbreak of crisis Japanese stock market prices declined sharply and this has limited commercial banks to lend more funds for domestic industry. In the third quarter of 2008 new loans for equipment funds declinded by $9 \%$, followed by $10 \%$ decline in fourth quarter (Kawai \& Takegi, 2009). Lack of funds caused industrial production decline and in combination with sharp appreciation of yen export-oriented firms have faced business problems. In January 2009 overall export was reduced for 50\% than in September 2008. Negative growth $(-6,2 \%)$ and reduced export of capital goods required strong measures in order to create right path of recovery.

\section{Monetary response to crisis}

With crisis started to spread, central banks were fully aware that they must react immediately if they want to help economies not to fall into deeper recession. Central banks want to rebuild monetary systems after shocks and crisis and it was a right moment to change the face of monetary strategy that was implemented until the crisis. It is always good to have new way of thinking, because every new crisis differs from the other and 
with the evolution of crisis some well-known measures can be useless. This time it was a right moment for implementing some unconventional methods in order to solve crisis.

First measure, which FED had implemented, was reducing the federal funds rate. From the beginning of the crisis in September 2007 until the end of December 2008 federal funds rate was reduced from $5,25 \%$ to $0,25 \%$, which was the lowest level in FED history. FED knew that relying on reduced federal funds rates will not be sufficient on a long-term, because most of assets were not provided to banks in a way that FED wanted. By the end of 2009 unemployment rate was $10 \%$, while annual inflation rate was $2,63 \%$ which was higher than aimed target of $2 \%$.

When traditional transmission mechanisms did not provide enough assistance, FED has started with direct involvement on interbanking market. FED introduced emergency credit facilities, which goal was to increase liquidity of financial market and its participants. FED has set up liquidity facilities in order to provide funds to banks at a competitive rate lower than discount rate through auctions (Mishkin, White, 2014, p. 7-9). These facilities were important for investment banks, because they could increase their assets with purchasing commercial papers, mortgage backed- securities and other kind of papers. During the first few months of the crisis overall assistance through facilities was $\$ 480$ million and by the end of 2008 it reached $\$ 1,6$ trillion.

Another measure that FED implemented in order to improve market liquidity was quantitative easing (QE). This new strategy is a support to monetary policy, where FED directly assists to market participants. FED tried to stimulate aggregate demand and consumption, but also to prevent further unemployment rate increase with buying long-term securities especially US Treasury securities, agency debt and agency mortgage-backed securities (Engen et al, 2015). FED has spent about $\$ 85$ billion per month on buying securities and this had impact on increasing FED's balance sheet. This unconventional policy reduced long-term interest rates, which were very important for mortgage market.

Table 1. Quantitative easing changes in asset holdings on the FED's balance sheet (billions of dollars)

\begin{tabular}{|c|c|c|c|c|}
\hline & $\begin{array}{c}\text { Treasury Security } \\
\text { Holdings }\end{array}$ & $\begin{array}{c}\text { Agency MBS } \\
\text { Holdings }\end{array}$ & $\begin{array}{c}\text { Agency Debt } \\
\text { Holdings }\end{array}$ & Total Assets \\
\hline $\begin{array}{c}\text { QE1 } \\
\text { (Mar.2009- } \\
\text { May 2010) }\end{array}$ & +302 & $+1,129$ & +168 & +451 \\
\hline $\begin{array}{c}\text { QE2 (Nov. } \\
\text { 2010- July } \\
\text { 2011) }\end{array}$ & +788 & -142 & -35 & +578 \\
\hline $\begin{array}{c}\text { QE3 (Oct. } \\
\text { 2012-Oct. } \\
\text { 2014) }\end{array}$ & +810 & +874 & -48 & +1.163 \\
\hline Total & $+1,987$ & $+1,718$ & +40 & $+2,587$ \\
\hline
\end{tabular}

Source: Labonte, 2015

Table 1 shows how FED used QE for purchasing securities. Total assets just before the crisis were less than $\$ 500$ billion and by the end of 2014 they were $\$ 2,5$ trillion which 
is five times larger than before the crisis. QE had impact on increasing bank reserves. In August 2008 value of bank reserves was about $\$ 46$ billion and by the end of same year it was $\$ 820$ billion. This value continued to increase in October 2009 when it exceeded $\$ 1$ trillion, while at the end of 2014 it was about $\$ 280$ trillion. This was a sign that banks were on a recovery path.

Implementing all these measures brought modest, but needed growth for US economy. Meanwhile, FED switched to explicit inflation targeting, where target goal was $2 \%$. During the most period of the crisis inflation rate remained below $2 \%$ which prooved that measures did not brought big inflatory pressure. Money supply did not generate inflatory pressure due to economic surplus, relatively good situation on credit market and well adopted inflatory expectations. Price stability, unemployment rate and GDP growth have strong connections, but strength of economy also allows FED to implement some unconventional methods in order to solve problems.

In Europe, ECB rapidly reduced main financing rate by 50 basis points and until May 2009 all key rates were reduced by 325 basis points. The main financing rate was at $1 \%$, which was the lowest in ECB history. This was still not good enough for improving market liquidity, because of negative growth and high unemployment rate.

ECB also adopted some non-standard measures to support financing conditions and credit flows in euro area which could be achieved through reductions of key interest rates. The unconventional measures that ECB used were: fixed-rate full allotment, extension of the maturity of liquidity provision, extent of collateral eligibility, currency swap agreements and covered bond purchase programme (CBBP) (Cour-Thimann, Winkler, 2013). Fixed-rate full allotment was designed to support the short-term funding needs of banks, with maintaining and enhancing the availability of credits to households and companies at accessible rates. Extension of the maturity of liquidity provision extended the maximum maturity of the long-term refinancing operations (LTROs) with keeping money market rates at low level so refinancing operations between banks in euro zone will become easier. As for collateral eligibility, ECB has already accepted private securities, but with the outbreak of the crisis asset-backed securities were also accepted as a collateral, because ECB decided to refinance non-liquid assets due to liquidity problems. Currency swap arrangement was a part of deal between ECB and FED. This measure will help ECB to provide liquidity in foreign currency (US Dollar), at various maturities and against euro-denominated collateral. ECB also decided to start with buying covered bond in order to revitalise bond market and increase money supply needed for liquidity. From July 2009 to June 2010, 422 different bond were purchased on primary and secondary market for a total amount of $€ 60$ billion (ECB, 2010). Covered bonds with maturities of three to seven years were purchased and were hold until maturity. 
Graphic 1. Changes in monetary aggreagtes M1 and M3 in euro zone for 2002-2012 (in \%)

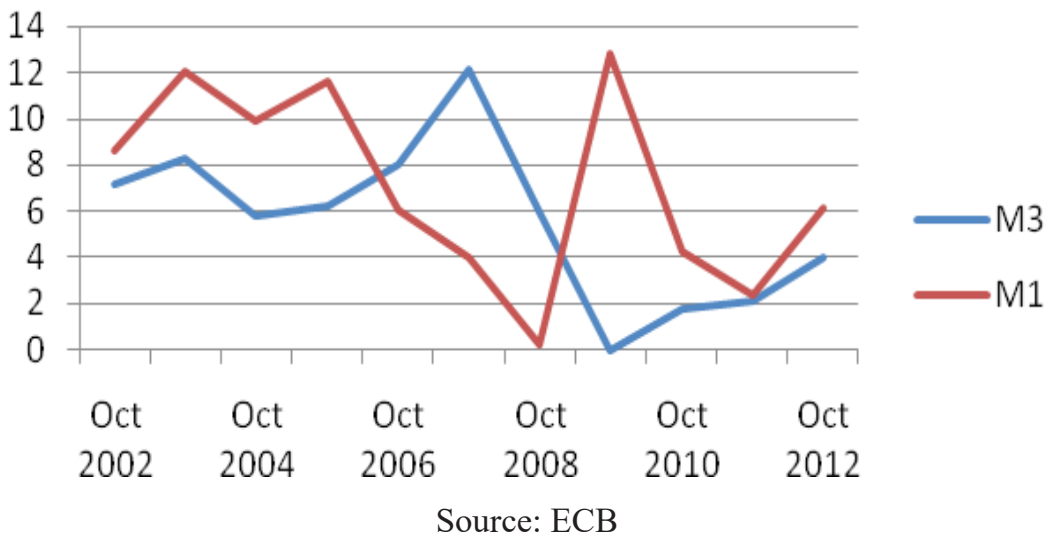

Graphic no.1 shows how M1 and M3 target have changed in last ten years. M1 aggregate has grown faster than M3 until 2006, but since the beginning of the crisis it is clear that M3 has started to grow faster. With the outbreak of sovereign debt crisis and appearance of deflation in 2010 M1 started to grow again and by October 2012 it had just a little more growth then M3. This growth of M1 was result of double interest rate increase in April 2011 to 1,25\% and in July 2011 to 1,50\%.

With the emerge of sovereign debt crisis in Greece ECB had to go with more unconventional methods and at that moment ECB became a true committed lender of last resort for banking system. ECB decided to extend the maturity of LTROs with a maturity of 36 months and the option of early repayment after one year (Pattipeilohy et al., 2013). In December 2011 ECB lent about $€ 490$ billion to banks and in February 2012 more $€ 530$ billion. Problem at bond markets in Italy and Spain forced ECB for new measures. This time ECB bought bonds in stressed countries for a total amount of $€ 220$ billion and this caused the increase of ECB balance sheet. Refinancing rate was cut to $0,25 \%$ in November 2013 and same thing happened to marginal lending facility rate and deposit rate that were reduced to $0,75 \%$ and $0,00 \%$. In June 2014 refinancing interest rate was again reduced to $0,15 \%$, the marginal lending facility rate to $0,40 \%$ and the deposit rate to $-0,10 \%$ as a part of anti-deflation plan (Rodriguez \& Carrasco, 2014).

$\mathrm{BoJ}$ immediate response to crisis was allowing unlimited amounts to banks at near zero rates through special-funds-supplying operations (SFSOs). Banks would count on the amount of loan that was equal to the amount of available collateral (commercial papers and corporate debts) that they had. This way, BoJ decide to take direct involvement in market and it started to buy Japanese government bonds, corporate bonds and commercial papers. Per month BoJ has spend about $¥ 6$ trillion for purchasing these papers. By the end of 2009 BoJ announced to replace SFOs with fixed-rate operations (FROs). BoJ offered $¥ 10$ trillion in 3 months maturity with later increase to $¥ 20$ trillion and $¥ 10$ trillion in 6 month maturity. What is most important is that BoJ opened Growth Supporting Funding Facility (GSSF) to support economy development. Export-oriented companies could take loans from banks on short-term (1 year), which could be extended to 4 years at fixed rate. This brought a slight increase of industrial production and export, but still not good enough to get out of recession. 
By the end of 2010, BoJ announced that Asset Purchase Program (APP) will be established as a part of comprehensive monetary easing. This also includes lowering the target for uncollateralized overnight call rate from 0,1 to $0,0 \%$ and clarifying the conditions for exiting the zero interest rate payment. Purchasing of assets will also include exchange-traded funds, Japanese real estate investment trusts and many other private assets (Fawly \& Neely, 2013). Through this program BoJ initially provided $¥ 35$ trillion, with additional $¥ 20$ trillion in future. From October 2011 to December 2012 BoJ purchased Japanese government bonds and Treasury Bills for $¥ 60$ trillion and private assets for $¥ 1$ trillion. Meanwhile, BoJ provided additional $¥ 6$ trillion for growth projects, which was shown as a right move because increased domestic demand has caused higher growth rate in $2012(1,8 \%)$ and that was a signal of recovery. Although more funds were allowed to companies in order to increase their domestic and international activities, inflation rate remained around $0 \%$.

Graphic 2. Monetary base changes in EU, Japan and EU for 2008-2013 (in\%)

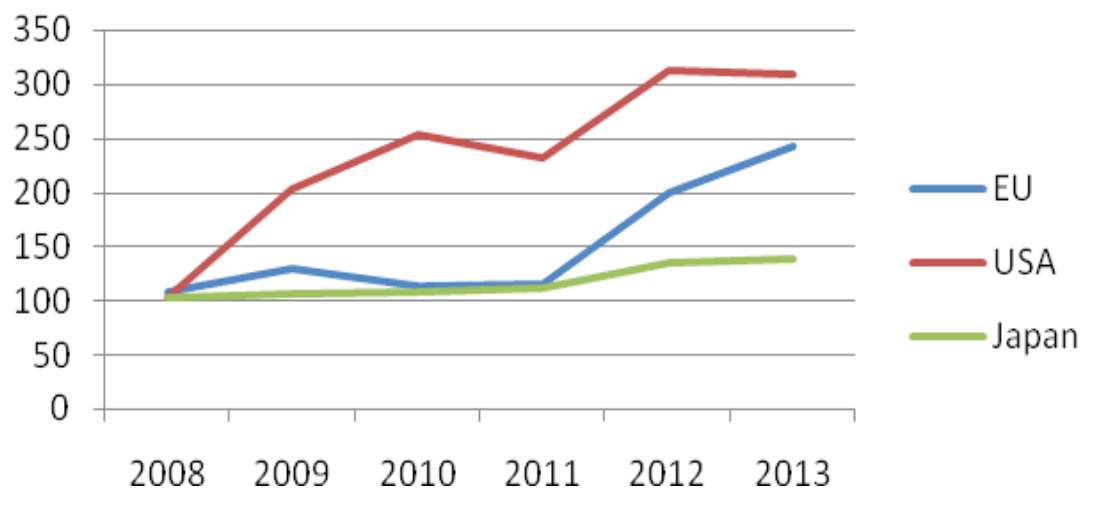

Source: BoJ, ECB, FED

Monetary measures that have been implemented by central banks in EU, Japan and USA increased monetary base. That increase was much higher and faster in USA, because FED had to react with enourmous injection of money supply to market, since crisis has started in USA first. From graphic 2 it can be seen that other two central banks $\mathrm{BoJ}$ and ECB have also reacted with increasing money supply, but their responses were slow and not in same intensity like in USA. After 2011 monetary base has significally increased with the implementation of unconventional financial methods. These methods produced more money supply, which is important for the recovery of cruicial markets. With the increase of monetary base, there was a fear that too much money on market will produce inflatory processes. This didn't happen, because inflatory expectations were on place and monetary authorities have directed money to right places where existed huge money demand. This time inflatory rates didn't create problem for central banks. 


\section{New direction in implementation of monetary strategies}

With every new crisis central banks have to rearrange their goals, instruments and mechanisms in order to improve all monetary aspects and avoid crisis. With last crisis it was a final moment for central banks to quit with their passive role on market. Central banks have also started to follow assets prices and try to control their changes in order of achieving financial stability (Mishkin, 2006). Direct involvement of central banks was result of too much deregulation on market, which only created space for participants with low-quality liquidity and solvency. This led to big market anomalies and created more troubles for global economy. In that situation states and their central banks had to find new ways for dealing with problems and to create better environment for market participants.

Last financial crisis showed that holding both financial and price stability represents very hard task. During the crisis these two kinds of stability showed that they have very strong interaction and that bringing their relation back to normal will help in solving crisis. Many central banks are implementing monetary policy in a direction of price stability, because variations of inflation rate can cause problems for manufacturing and trading sections. Also, when country has huge external debt inflation rate variations delay quick repayment of debt. Achieving financial and price stability at the same time require development of additional monetary instruments and policies of creditworthiness regulation (Geraats, 2010). Monetary sector has become very sensitive on changes at financial markets and this influenced central banks to start developing new strategies that can solve the problem of financial disbalance. Monetary problems are linked with financial problems and this the main reason why 14 out of 18 central banks in eurozone have improved supervisor role and this also happened with other central banks out in world (Zsolt, Silvia, 2013).

Liquidity issues are important task for every central bank. When they become problem central bank can use some measures for solving them. Central banks usually use open market operations for increasing liquidity or sometimes create credit programmes for organisations that have liquidity problems. It does not happens often, but sometimes central bank is purchasing specific type of assets to increase the liquidity of market like during the last crisis. These kind of assets are usually government bonds and their purchase also increases liquidity of central bank and its balance sheet. For central banks it is very important to discover the background of monetary shock in order to implement right measures. If the shock had origin at assets markets, then there would be a problem of market liquidity and that can be a signal for central bank reaction (Krstic et al, 2010). This happened during the last crisis.

Table 2. Central banks measures in response to the crisis

\begin{tabular}{|c|c|c|c|c|c|c|c|}
\hline & FED & ECB & BoJ & BoE & BoC & Riksbank & SNB \\
\hline $\begin{array}{c}\text { Lowering rates to very low } \\
\text { levels }\end{array}$ & $\mathrm{x}$ & $\begin{array}{c}\text { De } \\
\text { facto }\end{array}$ & $\mathrm{x}$ & $\mathrm{x}$ & $\mathrm{x}$ & $\mathrm{x}$ & $\mathrm{x}$ \\
\hline $\begin{array}{c}\text { Increasing liquidity } \\
\text { provision to financial } \\
\text { institutions }\end{array}$ & $\mathrm{x}$ & $\mathrm{x}$ & $\mathrm{x}$ & $\mathrm{x}$ & $\mathrm{x}$ & $\mathrm{x}$ & $\mathrm{x}$ \\
\hline
\end{tabular}




\begin{tabular}{|c|c|c|c|c|c|c|c|}
\hline $\begin{array}{c}\text { Interventing directly in } \\
\text { wider segments of the } \\
\text { financial market }\end{array}$ & $\mathrm{x}$ & $\mathrm{x}$ & $\mathrm{x}$ & $\mathrm{x}$ & & $\mathrm{x}$ \\
\hline $\begin{array}{c}\text { Purchasing long-term } \\
\text { government bonds }\end{array}$ & $\mathrm{x}$ & $\mathrm{x}$ & $\mathrm{x}$ & & & \\
\hline $\begin{array}{c}\text { Supporting specific } \\
\text { institutions }\end{array}$ & $\mathrm{x}$ & & $\mathrm{x}$ & $\mathrm{x}$ & & $\mathrm{x}$ & $\mathrm{x}$ \\
\hline
\end{tabular}

Source: Minegishi, Cournede, 2010

Liquidity support for banking system was crucial in process of economic recovery. FED and BoJ have approved large increases in monetary base due to substantial assetpurchase programmes. Huge liquidity support had impact on central banks balance sheets increase and this way monetary authorities have shown how serious they care about monetary sector. Liquidity injections were related to the lender of last resort function, which only helped central banks to become dominant market participants.

Keeping short-term interest rates at zero bound for a substantial period of time helped in lowering long-term interest rates and raised inflation rates, which resulted in reducing the real interest rate (Mishkin, 2010). By steering the level of key interest rates, the central bank effectively manages the liquidity conditions in money market and pursue its primary objective of maintaining price stability over the medium term (Meric, 2012). This turned markets from being insufficient to sufficient ones.

\section{Conclusion}

Every crisis changes the way of implementing certain monetary strategy, but the last one change the whole concept of monetary policy. Crisis has left many people without job, led to bankruptcy of many companies, caused shocks on financial markets and change overall expectations. Many strategies like inflation targeting were facing with difficulties on short and long -term and that is reason why some unconventional tools have become significant to overall performances of national economies.

Developments in the financial sector have a far greater impact on economic activity than everyone really expected. Mortgage market, especially subrprime mortgage caused huge losses on a relatively small part of financial market. Central banks believed that these shocks could be manageable, but they were wrong after the collapse of few depository and insurance companies. Authors have found that due to intensity of crisis, central banks were forced to change monetary strategies and to start with the implementation of some unconventional measures. The results of implementation were different because of certain specifics of the economies, but it was prooved that solving crisis could not go without implementation of unconventional monetary rules. Creating credit programmes for lending money to banks and financial institutions, quantitative easing and shaping expectations about the future path of interest rates are additional measures that central banks do not use every day.

Inflation targeting has become important strategy in process of economic stabilisation. Since 2012 FED has started with explicit inflation targeting where inflation 
is long-term goal. This change will help to keep inflation expectations at safe level which can help in achieving price and long-term interest rates stability. When real inflation expectations exist central bank will have bigger responsibility in taking care of this problem. ECB announces explicit inflation objective, but still refuses to treat it like a target because of possible public misunderstanding. Inflation targeting can help ECB in recovery process, but there is a still enough place for bigger involvement at European financial markets.

\section{References}

Beder, S. (2009). Neoliberalism and the global financial crisis. Social Alternatives, $8(1), 17-21$.

Borde, C., Clerc, L. (2004). Price stability and the ECB's monetary policy strategy. Banque de France. Paris.

Cour-Thimann, P., Winkler, B. (2013). The ECB's non-standard monetary policy measures - The role of institutional factors and financial structure. Oxford Review of Economic Policy, 28(4), 765-805.

ECB. (2013). The ECB's response to the financial crisis, ECB Monthly Bulletin, October. https://www.ecb.europa.eu/pub/pdf/mobu/mb201010en.pdf. (accessed on 27th August 2015).

Engen, E., Laubach, T. \& Reifchneider, D. (2015). The Macroeconomic Effects of the FED's Unconventional Monetary Policies. Federal Reserve. Washington. http:// dx.doi.org/10.17016/FEDS.2015.005. (accessed on 14th November 2015).

Englander, S. (1991). Optimal Monetary Policy Design: Rules Versus Discretion Again. Quartely Review 15, 65-79.

Fahr, S., Motto, R., Rostagno, M., Smets, F. \& Tristani, O. (2011). A monetary policy strategy in good and bad times - lessons from the past. Working Paper No. 1336. ECB. Frankfurt.

Fawly, B. \& Neely, C. (2013). Four stories of quantitative easing. Review, 95(1), 51-88

Geraats, M.P. (2010). Price and financial stability: dual or dueling mandates?. 38th Economic Conference of Oesterreische Nationalbank, 56-63. Oesterreische Nationalbank. Vienna.

Hubbard, G. (2005). Money, the Financial system and the Economy. Pearson. Boston.

Kawai, M. \& Takegi, S. (2009). Why was Japan Hit So Hard by the Global Financial Crisis? ADBI Working Paper 153. Asian Development Bank Institute. Tokyo.

Krstić, B., Marinković, S. \& Jemović, M. (2010). Aktuelne kontraverze o nadležnostima centralne banke u odnosu na njene tradicionalne funkcije. Ekonomske teme 4, 481-498.

Labonte, M. (2015). Monetary Policy and the Federal Reserve: Current Policy and Issues for Congress. Congressional Research Service. Washington.

Merić, M. (2012). Unconventional measures of monetary policy in the function of financial stability. Ekonomika 2, 218-235. 
Minegshi, M. \& Cournede, B. (2010). Monetary Policy Response to the Crisis and Exit Strategies, OECD Economics Departement Working Paper No. 753. OECD Publishing. https://dx.doi.rg/101787/5klm6xm79956-en. (accessed on 7th September 2015)

Mishkin, F. (2011). Monetary Policy Strategy: Lessons from the Crisis. NBER Working Paper No. 16755. National Bureau of Economic Research. Cambridge.

Mishkin, F. (2006). Strategija monetarne politike: Kako smo dospeli ovde? Paneconomicus 4, 359-388.

Mishkin, F., White, E. (2014). Unprecedented Actions: The Federal Reserve's Response to the Global Financial Crisis in Historical Perspective. Working Paper No. 209. Federal Reserve Bank. Dallas.

Pattipeilophy, C., Willem, J., Tabbae, M., Frost, J. \& Haan, J. (2013). Unconventional monetary policy of the ECB during the financial crisis: An assessment and new evidence. Working Paper No. 381. Nederlandsche Bank. Amsterdam.

Perić, M., Marić, R. (2015). Trade policy in neoliberal era. Ekonomika, 61(3), 163 172.

Rodriguez, C., Carrasco, C. (2014). ECB policy responses between 2007 and 2014: A chronological analysis and a money quantity assesments of their effects. Faculty of Economics. Bilbao.

Veselinović, P. (2012). Izazovi ekonomske nauke u uslovima globalne ekonomske krize. Ekonomske teme 4, 433-450. 